\title{
Mitochondrial DNA Introgression in the European Abalone Haliotis tuberculata tuberculata: Evidence for Experimental mtDNA Paternal Inheritance and a Natural Hybrid Sequence
}

\author{
Alain Van Wormhoudt • Valérie Roussel • \\ Gercende Courtois · Sylvain Huchette
}

Received: 16 April 2010 /Accepted: 17 September 2010 /Published online: 12 October 2010

(C) Springer Science+Business Media, LLC 2010

\begin{abstract}
Two subspecies of the European abalone have been morphologically recognized: Haliotis tuberculata tuberculata, present in the North Atlantic, and Haliotis tuberculata coccinea, present in the Canary Islands. Among the different nuclear markers used to differentiate these two subspecies, the sperm lysin gene was the most reliable, leading to a $2.2 \%$ divergence. Concerning the subunit I of the mitochondrial cytochrome oxydase gene (COI), we observed a difference of $3.3 \%$ between the two subspecies. In the North Atlantic, an introgression of mitochondrial DNA from $H$. tuberculata coccinea to $H$. tuberculata tuberculata was evident in around $30 \%$ of individuals. Due to this difference, we were able to experimentally detect the transfer of paternal mitochondrial DNA (mtDNA) by specific quantitative polymerase chain reaction measurements. The presence of the two mtDNA signatures was also detected in $20 \%$ of individuals tested in the field. Moreover, one mt DNA hybrid sequence was identified. The sequencing of this mitochondrial DNA hybrid revealed a mosaic structure with many specific mutations. The origin of this hybrid sequence is discussed.
\end{abstract}

A. Van Wormhoudt $(\bowtie) \cdot$ V. Roussel

CNRS UMR 7208, Station de Biologie Marine du Muséum

National d'Histoire Naturelle,

29900 Concarneau, France

e-mail: avw@mnhn.fr

\section{G. Courtois}

Grupo de Investigación en Acuicultura (ICCM \& IUSA),

P.O. Box 56, 35200 Telde,

Las Palmas, Canary Islands, Spain

S. Huchette

France Haliotis,

Kerazan,

29880 Plouguerneau, France
Keywords Abalone - Haliotis mtDNA introgression · mtDNA paternal inheritance $\cdot \mathrm{mtDNA}$ natural hybrid sequence

\section{Introduction}

Haliotis tuberculata is the only abalone species present in Europe (Mgaya et al. 1995). This marine vetigastropod mollusc has a high economic importance, as the species is both fished and farmed. Three subspecies have been described, based on morphological characteristics: Haliotis tuberculata tuberculata Linnaeus, 1758, in the Atlantic; Haliotis tuberculata lamelosa Lamark, 1822, in the Mediterranean Sea; and Haliotis tuberculata coccinea Reeve, 1846, in the Canary Islands (Mgaya et al. 1995). But, this distinction presented some limits. The distribution of the species extends from the Channel Islands to Senegal (Huchette and Clavier 2004). The two subspecies $H$. tuberculata tuberculata and $H$. tuberculata coccinea have been separated for at least 1-1.5 million years ago (mya) following the opening of the Gibraltar strait and the establishment of opposing marine currents. Due to changes in the level of the sea during the Pleistocene, we believe that these subspecies have been in contact on some occasions after the closure(s) of this strait.

The nuclear rDNA $18 \mathrm{~S}$ gene displays relatively few variant nucleotide positions in Haliotidae (Coleman and Vacquier 2002). The different $H$. tuberculata subspecies were characterized by a common $18 \mathrm{~S}$ rDNA structure (Giribet and Wheeler 2002). It is important to note, however, that one sequence reported in the literature, by Scharzpaul (2002, NCBI, accession number AF534995), presented some different features (in particular at the $5^{\prime}$ end, 
with some extra nucleotides or some changes of nucleotides), whereas few changes were detected at the 3 'end. This discrepancy is under investigation (unpublished) as it suggested the existence of different $18 \mathrm{~S}$ in this species. By contrast, intergenic spacer regions of nuclear ribosomal genes transcribed into RNA (ITS1 and ITS2) have been used with success at the species level (Coleman and Vacquier 2002) but also to separate $H$. tuberculata lamelosa from $H$. tuberculata tuberculata: $H$. tuberculata coccinea was not used in this study. Other nuclear markers have been used in Haliotidae to differentiate subspecies such as microsatellites (Selvamani et al. 2000; Elliott et al. 2000; Evans et al. 2000; Huang et al. 2000; Tang et al. 2005), sperm lysin genomic precursor (Huang et al. 2000; Clark et al. 2007; Swanson et al. 2001; Lee and Vacquier 1995), and the intron of the gene of abalone homolog for oyster ribosomal protein L5 ( $r p l 5$; Clark et al. 2007). These latest were used with success to separate $H$. tuberculata subspecies.

By using mitochondrial COI as a marker (Elliott et al. 2000; Hamm and Burton 2000; Maynard et al. 2005; An et al. 2005), we previously confirmed the existence of two $H$. tuberculata subspecies in the Canary Islands and in the North Atlantic, differing by about 3.3\% in their sequences. Mitochondrial DNA (mtDNA) consists of a circular genome, which in most species, including $H$. tuberculata (Van Wormhoudt et al. 2009), contains 37 genes. For decades, it has been assumed to be exclusively maternally inherited (Birky 1995), but recently, due in part to the evolution of sequencing techniques, paternal mtDNA inheritance was demonstrated in mussels (Skibinski et al. 1994a, b; Zouros et al. 1992). In these animals, the dominant mtDNA type in male gonads is the male-transmitted type (GarridoRamos et al. 1998), by a mechanism which has just begun to be elucidated (Breton et al. 2006).

mtDNA homologous recombination has been well documented in mussels (Ladoukatis and Zouros 2001) and clams (Passamonti et al. 2003) where double parental inheritance has been demonstrated and also, more recently, in species with conventional inheritance, such as salmon (Ciborowski et al. 2010). It was assumed recently that the extensive study of mtDNA genomes may provide evidence for signatures of past recombination events (Rokas et al. 2003).

Hybridization between closely related species is present in natural populations and was previously described between Haliotis ovina and Haliotis varia (Owen et al. 1971), and, more recently, introgression of mtDNA was detected between these two species (Degnan et al. 2006). Recently, a $30 \%$ mtDNA signature of $H$. tuberculata coccinea was detected in Brittany and in Normandy populations (Roussel et al. 2010). Thus, it constituted a material of choice for studying species hybridization and recombination.

In this paper, sperm lysin gene and mitochondrial DNA were used to differentiate the two $H$. tuberculata subspecies and characterize a mitochondrial introgression in North Atlantic $H$. tuberculata tuberculata populations. This introgression was used to demonstrate paternal mtDNA transfer on four selected crossings, controlled by microsatellite assignment. The existence of this transfer was also detected in natural abalone populations by quantitative polymerase chain reaction (PCR) hybridization. A natural mtDNA hybrid was completely sequenced.

\section{Materials and Methods}

\section{Sampling}

Around 700 individuals have been previously sampled in different areas of the known distribution of $H$. tuberculata, between the English Channel and the Canary Islands (Courtois et al. 2007; Roussel et al. 2010). Identification of the two North Atlantic subspecies (H. tuberculata tuberculata Linné, 1758 , and H. tuberculata coccinea Reeve, 1846) was done according to their morphological aspects every time this was possible (Geiger 1999, 2000; Geiger and Poppe 2000; Hardy 2007). From each individual, a mantle epipodite (approximately $100 \mathrm{mg}$ ) was removed from its foot periphery, transferred into $70 \%$ ethanol, and stored at $-20^{\circ} \mathrm{C}$ for DNA isolation.

\section{Taxonomic Identification of Subspecies}

DNA was extracted with the CTAB method (Doyle and Doyle 1987). PCRs were performed on $0.1 \mu \mathrm{g}$ of the DNAs.

$18 S$ and ITS1 Study Primers used for 18S-ITS1 amplification are positioned on the $5^{\prime}$ end of the 18S rDNA (18S sp2) and the $5^{\prime}$ end of the 5.8S rDNA (ITS3r). The amplicons included ITS1 in the sequence. $18 \mathrm{~S}$ sp2 is specific to $H$. tuberculata and deduced from the NCBI database: AF120511 (Giribet and Wheeler 2002) 5'-CTAAAGCTCC GACCCTTTCT -3' while ITS3r 5'-TTCGACSCACGAGC CRAGTGATC- $3^{\prime}$ is a consensus sequence for the internal transcribed spacer 1 .

All the reactions were done according to GE Healthcare procedure (Ready to Go PCR) at $52^{\circ} \mathrm{C}$. After electrophoresis, the bands were extracted directly from agarose gel, and DNA was extracted by the use of the Kit Wizard SV Gel System (PROMEGA).

The sequences of $18 \mathrm{~S}$ and ITS1 issued from the $18 \mathrm{~S}-$ ITS1 complex sequences were determined using internal primers. The sequence reaction was carried out on extracted PCR products with the use of the sequencing reagent BigDye (Applied). The initial phase of denaturation (2 min at $96^{\circ} \mathrm{C}$ ) was followed by 40 cycles at $96^{\circ} \mathrm{C}$ for $30 \mathrm{~s}, 50^{\circ} \mathrm{C}$ 
for $30 \mathrm{~s}$, and $60^{\circ} \mathrm{C}$ for $4 \mathrm{~min}$. The DNA sequences were determined by an automated sequencer (ABI 3130).

Sperm Lysin Study For sperm lysin gene, two primers were used, which have consensus sequences between $H$. tuberculata coccinea and $H$. tuberculata tuberculata (Lee and Vacquier 1992; Vacquier et al. 1997): Conslysfw 5'AAGTTGAAGTTGCTCTGAAGGT $-3^{\prime}$ and Conslysrev 5'- TATCTTCTCATCTACGAACAGC-3'.

CO I Study Primers used for mitochondrial CO I: COIfw: $5^{\prime}$ CCAGCTGGAGGAGGAGAYCC-3' and COIrev: 5' - GCGT CTGGGTAGTCTGARTAKCG-3' were specific for the $3^{\prime}$ conserved gene area of COI. The sequence reaction was carried out on extracted PCR products as previously described.
The nearly complete mitochondrial DNA sequence of a natural hybrid, collected in Normandy (Agon Coutainville), was obtained by PCR and compared with the sequence of $H$. tuberculata tuberculata and $H$. tuberculata coccinea (Van Wormhoudt et al. 2009). After DNA extraction, three combined PCRs were realized using: CO3ATG (5'ATGACCCGAAGACCTTTTCATCT-3') and NAD5fw (5'GCCATCAACATAGTTAAAAC-3') as the first pair; CO2 (5'-ATGCCTCCTAACAATTAAAGCA-3') and cytoB3 (5'CCGTTCCTTTTAGGGGATCCGG-3') as the second pair; and cytoB2R (5'- AGGCTGAATGTGGACCGGCG-3') and tRNAglu (5'-GGTGTAGGTAGCACATTAGGTTTTC-3'), as the third pair.

The TripleMaster mix PCR system from Eppendorf was used to obtain long PCR fragments.

\author{
AF296860_Roscoff \\ AF296861_Naples \\ tuberculāta \\ coccinea \\ marmorata \\ diversicolor-2 \\ rugosa_2 \\ AF296860 Roscoff \\ AF296861_Naples \\ tuberculāta \\ coccinea \\ marmorata \\ diversicolor-2 \\ rugosa_2 \\ AF296860 Roscoff \\ AF296861_Naples \\ tuberculāta \\ coccinea \\ marmorata \\ diversicolor-2 \\ rugosa_2 \\ AF296860 Roscoff \\ AF296861_Naples \\ tuberculāta \\ coccinea \\ marmorata \\ diversicolor-2 \\ rugosa_2

AF296860_Roscoff
AF296861_Naples
tuberculata
coccinea
marmorata
diversicolor-2
rugosa_2

Fig. 1 Nucleotide sequence of internal spacer 1 (ITS1) from different Haliotidae. In bold, an additional sequence which separated Haliotis rubra and $H$. diversicolor used as a control and collected by us in "La Reunion" (Indian Ocean) and around the Taiwan Island (Taschi

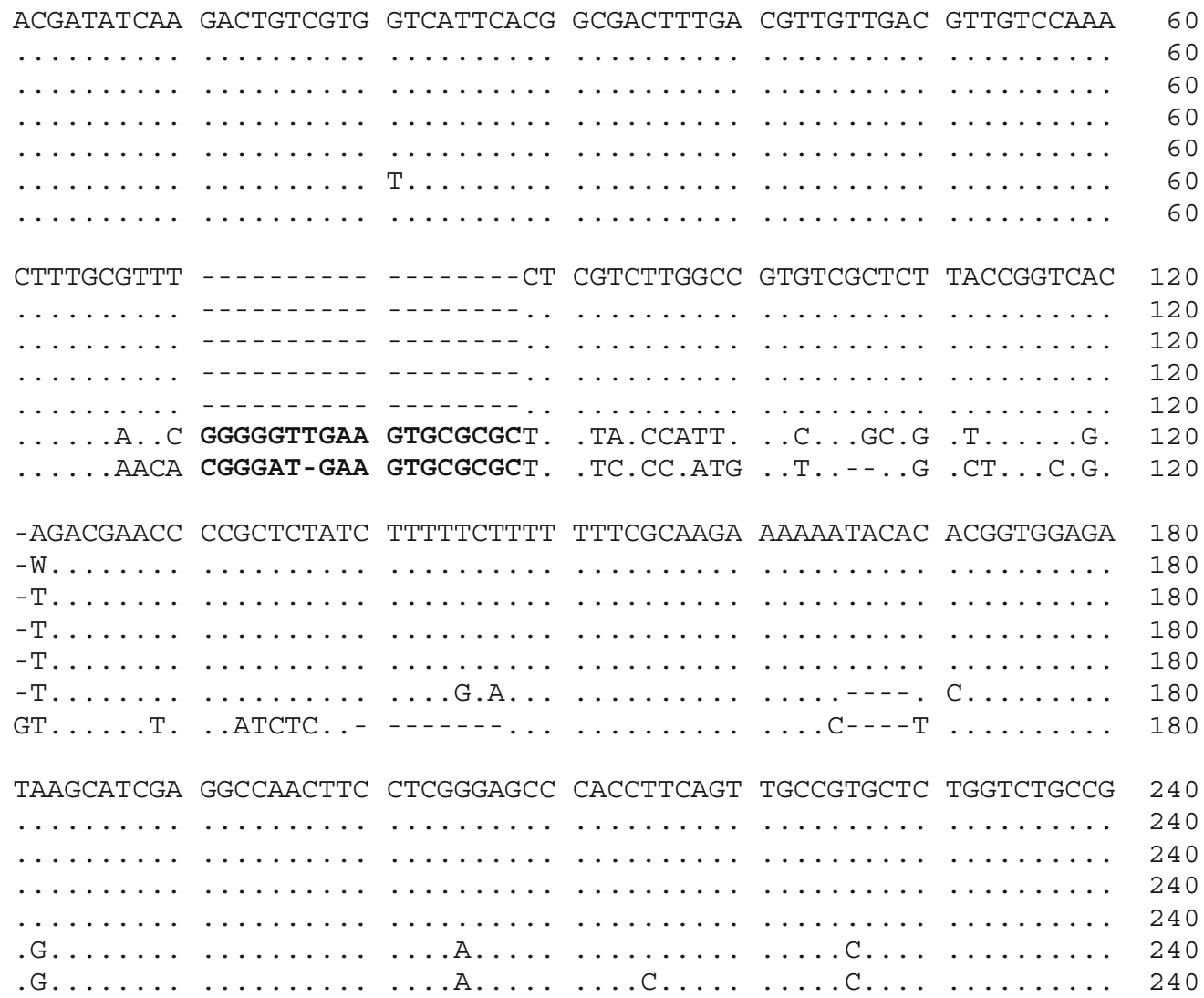

CCGGACGCGG TGACTT--TC AGTAATGAAA ACCTCTCA 278

$\ldots \ldots \ldots \ldots \ldots \ldots \ldots \ldots \ldots \ldots$

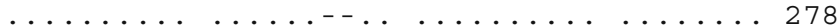

$\ldots \ldots \ldots \ldots \ldots \ldots \ldots \ldots \ldots$

$\ldots \ldots \ldots \ldots \ldots \ldots \ldots 278$

$\ldots$... . . .... T.......... 278

$\ldots \ldots$. ..... . . . . . . . . . . . 278 market, Pacific coast). No difference was reported from the different ITS1 sequenced, but one change in position 122 has been reported from literature (Coleman and Vacquier 2002) 


\section{Experimental Crossing}

Abalone families were produced in "France Haliotis" hatchery premises in Plouguerneau and obtained from parents collected from wild stocks in North Western Brittany (Plouguerneau and Roscoff). Each family was produced from a parental pair. Four couples of parents selected as $H$. tuberculata tuberculata from their sperm lysin sequences were crossed to obtain four full-sib families. The parents were selected in order to obtain four combinations of their mitochondrial DNA: clade $1 \times$ clade 1 , clade $1 \times$ clade 2 , clade $2 \times$ clade 2 , and clade $2 \times$ clade 1 . After fixation of the larvae on the settlement plates (Daume et al. 2003), 100 individuals of less than $0.5 \mathrm{~mm}$ were selected on the different plastic plates and extracted together for COI and nuclear gene analysis. Four of the biggest individuals, according to the four different crossings, were sampled; their DNA was extracted and controlled with the different microsatellites.
Microsatellites Assignment

Two multiplexes were used (Roussel et al. 2010): the first one including Haltub01, Haltub09, Haltub22, and Haltub25, and the second one including Haltub07, Haltub13, Haltub16, and Haltub24. For multiplex 1, PCR amplifications were carried out in a $10-\mu \mathrm{l}$ reaction volume containing $10 \mathrm{ng}$ of genomic DNA, $0.3 \mu \mathrm{M}$ of forward and reverse primers, and $1 \times$ multiplex mastermix (Qiagen) (containing HotStarTaq DNA polymerase, $\mathrm{KCl}\left(\mathrm{NH}_{4}\right) \mathrm{SO}_{4}$, and Tris- $\mathrm{HCl}$, and providing $3 \mathrm{mM} \mathrm{MgCl}$ and $200 \mu \mathrm{M}$ of each dNTP). For multiplex 2, PCR amplifications were carried out in a $10-\mu$ l reaction volume containing $10 \mathrm{ng}$ of genomic DNA, 0.3 (Haltub07, Haltub16, and Haltub24) or $0.4 \mu \mathrm{M}$ (Haltub13) of forward and reverse primers, and $1 \times$ HotstarTaq master mix (Qiagen) (providing a final concentration of 0.5 units HotStarTaq DNA polymerase, $1 \times$ PCR buffer with $1.5 \mathrm{mM} \mathrm{MgCl}_{2}$ and $200 \mu \mathrm{M}$ of each dNTP). We used the following thermotreatment on a Whatman Biometra Tgradient: 35 cycles with $94^{\circ} \mathrm{C}$ for $30 \mathrm{~s}, 56^{\circ} \mathrm{C}$

\section{EXON

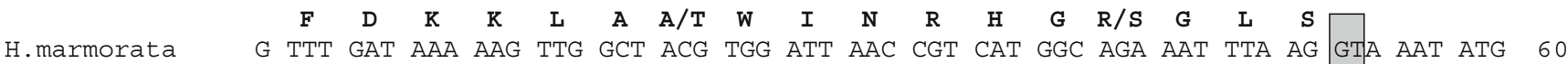

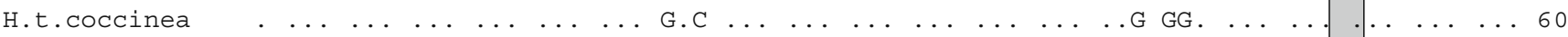

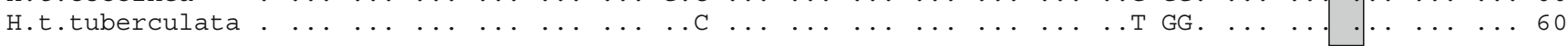

H.marmorata AGC TTA ATT TGA TGT TTG CAT AAA GAC TAA AGA TCA TGA AGC CAG CAC TTG CAC AAA GCG 120

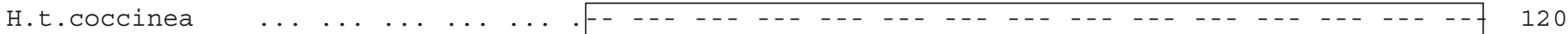

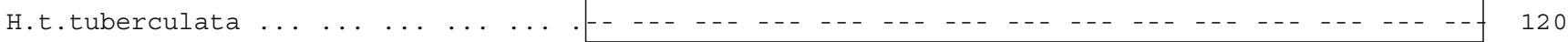

H.marmorata ACC TTA GCG CAG TTA GTA TGC TAA GAG CA- CTA AGA ACT ACG ATC CTG GTG CCA TTA AGT 180

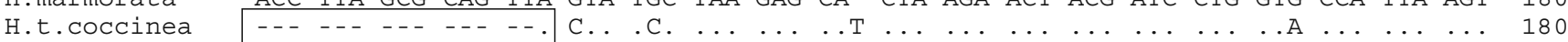

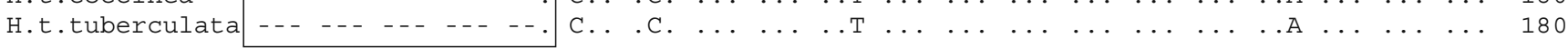

H.marmorata GGA TGC TGA GTA AAG AGT AAA GAT ACT GGC TCC ATA CAG TTA ATA TGA AAA GGT ATA CGA 240

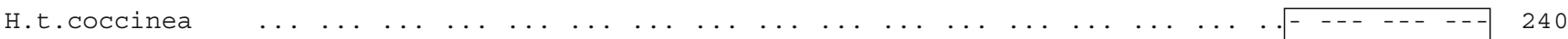

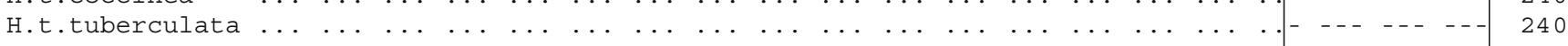

H.marmorata ATC GTA TTT CGC TTG ATC TTT AGT ATT TGT AAC AAT GTG AAA GTC CGT GCC TAT TTC TCG 300

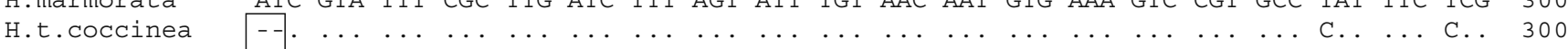

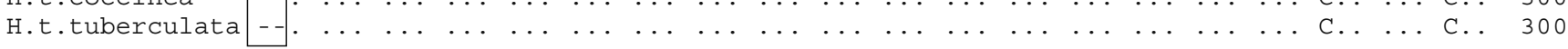

H.marmorata AGA AAT TAA GAT AAC ACT GCA AGG AGT TTT AAG ACT GTT GAA AGG TAA TAC GTG GCA GTG 360

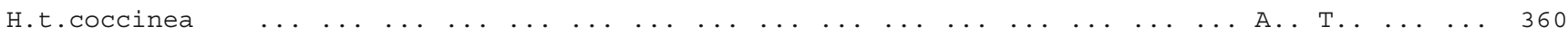

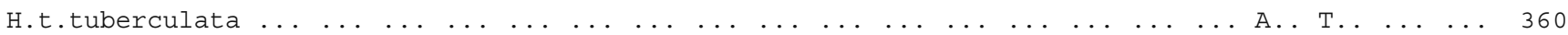

H.marmorata TTG ATA CAA GCG ATA CTG TAG TTG AGC ATG GCC TGC CAA GCA TAG CTA ACT GCA CTG ATC 420

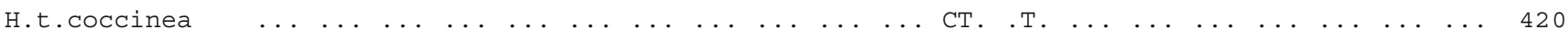

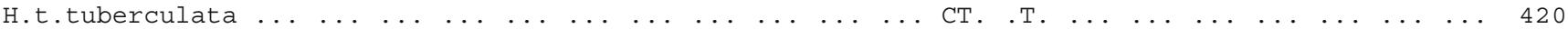

H.marmorata GCG AGG TAA CTA TTT TGT ATT GTA TTT CCA TC- TGT TGT AAA GTT GGT AGT GCA ATG TTT 480

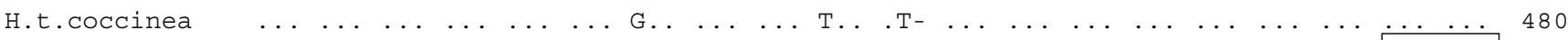

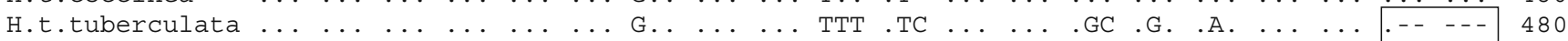

\begin{tabular}{|c|c|c|c|c|c|c|c|c|c|c|c|c|c|c|c|c|c|c|c|c|c|c|}
\hline \multirow[b]{3}{*}{ H.marmorata } & \multirow[b]{3}{*}{$\mathrm{CAT}$} & \multirow[b]{3}{*}{$\mathrm{CTT}$} & \multirow[b]{3}{*}{ TTG } & \multirow[b]{3}{*}{ AAT } & \multirow[b]{3}{*}{ CTG } & \multirow[b]{3}{*}{ TTT } & & \multicolumn{15}{|c|}{ EXON } \\
\hline & & & & & & & & & $\mathrm{A}$ & $\mathrm{V}$ & $Q$ & $\mathrm{~K}$ & $\mathrm{R} / \mathrm{K}$ & $\mathrm{T}$ & L & $\mathrm{Y}$ & $\mathbf{F}$ & $\mathrm{V}$ & $\mathrm{N}$ & $\mathrm{R}$ & & \\
\hline & & & & & & & dAG & $\mathrm{C}$ & GCA & GTT & CÁG & AAG & AGG & ACG & CTG & TAC & TTT & GTC & AAT & AGA & C & 539 \\
\hline H.t.coccinea & . G. & $\ldots$ & $\ldots$ & $\ldots$ & $\ldots$ & $\ldots$ & . & $\mathrm{T}$ & $\ldots$ & $\ldots$ & $\ldots$ & $\ldots$ & .A. & $\ldots$ & $\ldots$ & $\ldots$ & $\ldots$ & $\ldots$ & $\ldots \mathrm{C}$ & $\ldots$ & . & 539 \\
\hline H.t.tuberculata & . . & $\cdots$ & $\cdots$ & $\cdots$ & $\cdots$ & $\cdots$ & 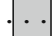 & . & $\cdots$ & $\cdots$ & $\cdots$ & $\cdots$ & . A. & $\cdots$ & $\cdots$ & $\cdots$ & $\cdots$ & $\cdots$ & $\ldots \mathrm{C}$ & $\ldots$ & . & 539 \\
\hline
\end{tabular}

Fig. 2 Nucleotide sequence of sperm lysin precursor gene from $H$. tuberculata subspecies and H. marmorata. Gray boxes indicate the beginning and the end of intron 3. White boxes indicate the different deletions 

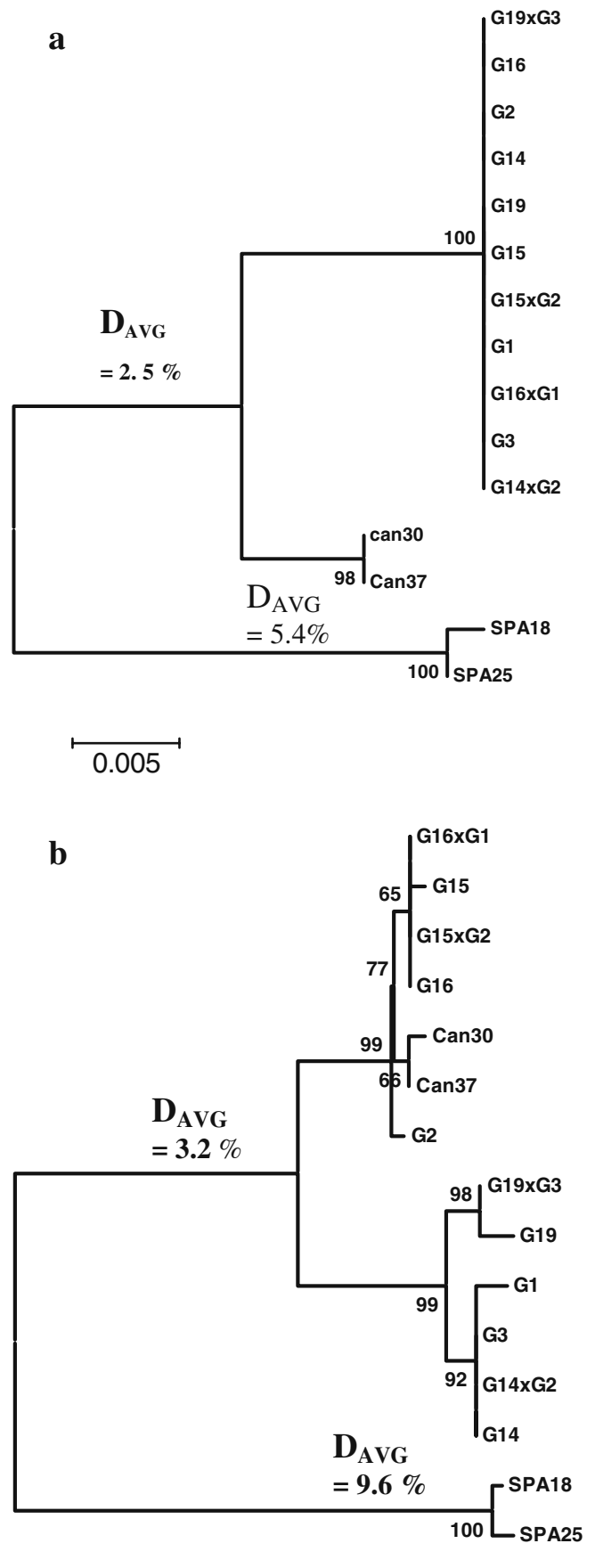

$\longmapsto 0.01$

Fig. $3 \mathrm{NJ}$ analysis of the different sperm lysin precursor genes (a) and COI haplotypes (b) of the different genitors and hybrids of $H$. tuberculata tuberculata compared with H. marmorata (SPA18 and SPA25) and H. tuberculata coccinea from Canary Islands (Can30 and Can37). The mean percentage of divergence was indicated. a The sperm lysin gene precursor separated well the three subspecies. b The COI sequences indicated an introgression of mtDNA signature from $H$. tuberculata coccinea in the $H$. tuberculata tuberculata from Brittany. COI, in which its sequence ranged from base 709 to base 1,273 of the coding sequence, are grouped into two clades and do not separate the two subspecies. Bootstraps as well as the percentage of divergence $\left(D_{\text {avg }}\right)$ is indicated on the figure
(Multiplex 1), or $50^{\circ} \mathrm{C}$ (Multiplex 2) for $90 \mathrm{~s}$; and $72^{\circ} \mathrm{C}$ for $60 \mathrm{~s}$. Before the first cycle, a prolonged denaturation step $\left(95^{\circ} \mathrm{C}\right.$ for $\left.15 \mathrm{~min}\right)$ was included, and the last cycle was followed by a 30 -min extension at $72^{\circ} \mathrm{C}$. Amplified products were diluted in formamide containing GENESCAN-350 (ROX) (Applied Biosystem) size standard, and size polymorphisms were screened using an ABI Prism 3130 DNA sequencer (Applied Biosystem). DNA fragments were analyzed using Genemapper software version 4.0 (Applied Biosystem).

\section{Quantitative PCR}

For CO I quantitative PCR (qPCR), four specific primers were designed. For specific $H$. tuberculata tuberculata amplification:

tub1fwsp 5' - TACCGTCGGGATAGACGGTAGAT-3', tub 2revsp 5' - CCGGTTAGGCCTCCTACGGTA-3'

And for specific $H$. tuberculata coccinea amplification:

$$
\begin{aligned}
& \text { cocc 3fwsp 5' - TACCGTCGGGATAGACGTAGAC-3' } \\
& \text { cocc2rev 5' - CCGGTTAGGCCTCCTACGGTG -3' }
\end{aligned}
$$

Please note that these primers only differ in a single base at their $3^{\prime}$ end. The amplifications were done in a volume of

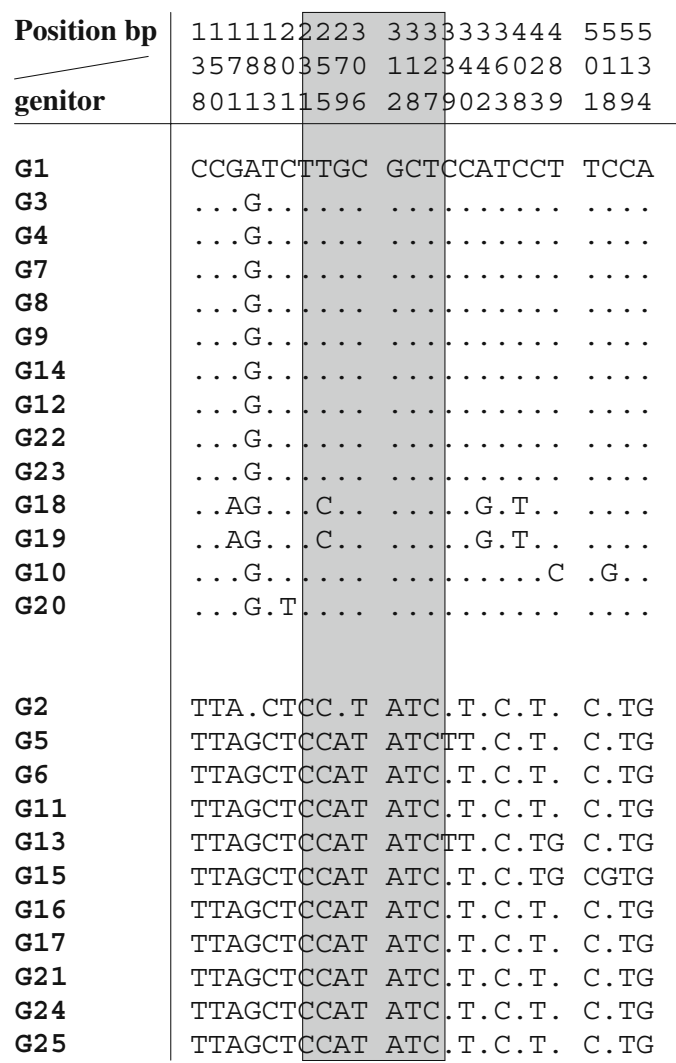

Clade 1

Clade 2

Fig. 4 COI dominant haplotypes of the different genitors previously to their selection for reproduction where only G1, G2, and G3 are used as males and G14, G15, G16, and G19 are used as females. The gray box corresponds to the bp changes in the amplified fragment during qPCR 
Table 1 Specificity of the different primers used for qPCR to amplify the different COI

\begin{tabular}{|c|c|c|c|c|}
\hline Genitors & Cross & Tubsp & Coccsp & Ratio/Ct \\
\hline \multicolumn{5}{|c|}{ Natural hybrids } \\
\hline G1 & & $2.35 X+18.25$ & $\mathrm{~nm}$ & - \\
\hline $\mathrm{G} 2$ & & $\mathrm{~nm}$ & $2.04 X+15.15$ & - \\
\hline G3 & & $2.11 X+16.40$ & $\mathrm{~nm}$ & - \\
\hline G4 & & $2.05 X+12.9$ & $\mathrm{~nm}$ & - \\
\hline G5 & & $\mathrm{nm}$ & $1.92 X+14.87$ & - \\
\hline G6 & & $\mathrm{nm}$ & $2.05 X+14.95$ & - \\
\hline G7 & & $2.08 X+13.81$ & $\mathrm{~nm}$ & - \\
\hline G8 & & $2.15 X+14.34$ & $\mathrm{~nm}$ & - \\
\hline G9 & & $1.87 X+16.23$ & $1.80 X+22.40$ & 128 \\
\hline G10 & & $2.05 X+13.74$ & $\mathrm{~nm}$ & - \\
\hline G11 & & $1.75 X+23.30$ & $1.95 X+15.5$ & 256 \\
\hline G12 & & $2.14 X+15.83$ & $\mathrm{~nm}$ & - \\
\hline G14 & & $1.80 X+16.10$ & $1.75 X+18.70$ & 32 \\
\hline G15 & & $\mathrm{nm}$ & $2.33 X+11.75$ & - \\
\hline G16 & & $\mathrm{nm}$ & $2.39 X+10.11$ & \\
\hline G17 & & $\mathrm{nm}$ & $2.30 X+14.40$ & - \\
\hline G19 & & $1.85 X+15.5$ & $1.80 X+22$ & 128 \\
\hline G21 & & $\mathrm{nm}$ & $2.25 X+13.36$ & - \\
\hline G23 & & $1.72 X+16.30$ & $1.70 X+24$ & 256 \\
\hline G24 & & $\mathrm{nm}$ & $2.23 X+15.28$ & \\
\hline \multicolumn{5}{|l|}{ Juveniles } \\
\hline & $\mathrm{G} 16 \times \mathrm{G} 1$ & $2.0 X+24.40$ & $1.99 X+15.47$ & 512 \\
\hline & $\mathrm{G} 14 \times \mathrm{G} 2$ & $2.35 X+14.40$ & $1.70 X+23.30$ & 512 \\
\hline & $\mathrm{G} 19 \times \mathrm{G} 3$ & $2.45 X+14.47$ & $\mathrm{~nm}$ & $\mathrm{~nm}$ \\
\hline & $\mathrm{G} 15 \times \mathrm{G} 2$ & $\mathrm{~nm}$ & $2.25 X+12.70$ & $\mathrm{~nm}$ \\
\hline
\end{tabular}

The equation of the curve corresponded to a dilution of factor 5 . The measurements were done in duplicate, and six to seven ranges of dilution were used. Efficiency ranged from $75 \%$ to $105 \%$ (slope 1.70 to 2.39 )

$15 \mu \mathrm{l}$ with $7.5 \mu \mathrm{l}$ of SYBR green PCR mix (Biorad), $0.5 \mu \mathrm{l}$ of each primer at $10 \mu \mathrm{M}, 5 \mu \mathrm{l}$ DNA at $0.1 \mu \mathrm{g} / \mathrm{ml}$, and $1.5 \mu \mathrm{l}$ RNAse free water. The same temperature of $60^{\circ} \mathrm{C}$ was used for hybridization and elongation. Serial DNA dilutions (1/5) were done from a stock solution of $0.1 \mu \mathrm{g} / \mu \mathrm{l}$ for tissues and of $0.01 \mu \mathrm{g} / \mu \mathrm{l}$ for cells. The absorbance was measured continuously on a myIQ Biorad single color detector.

\section{Data Analysis}

DNA sequences were aligned using the Clustal W accessory application of Bioedit (Hall 1999) and treated with Mega 4.02 (Kumar et al. 2004; Tamura et al. 2007). Minimum evolution trees were determined with ITS1 markers, and the average distance between the different clades was calculated according to the Kimura 2 parameter model (Kimura 1980).

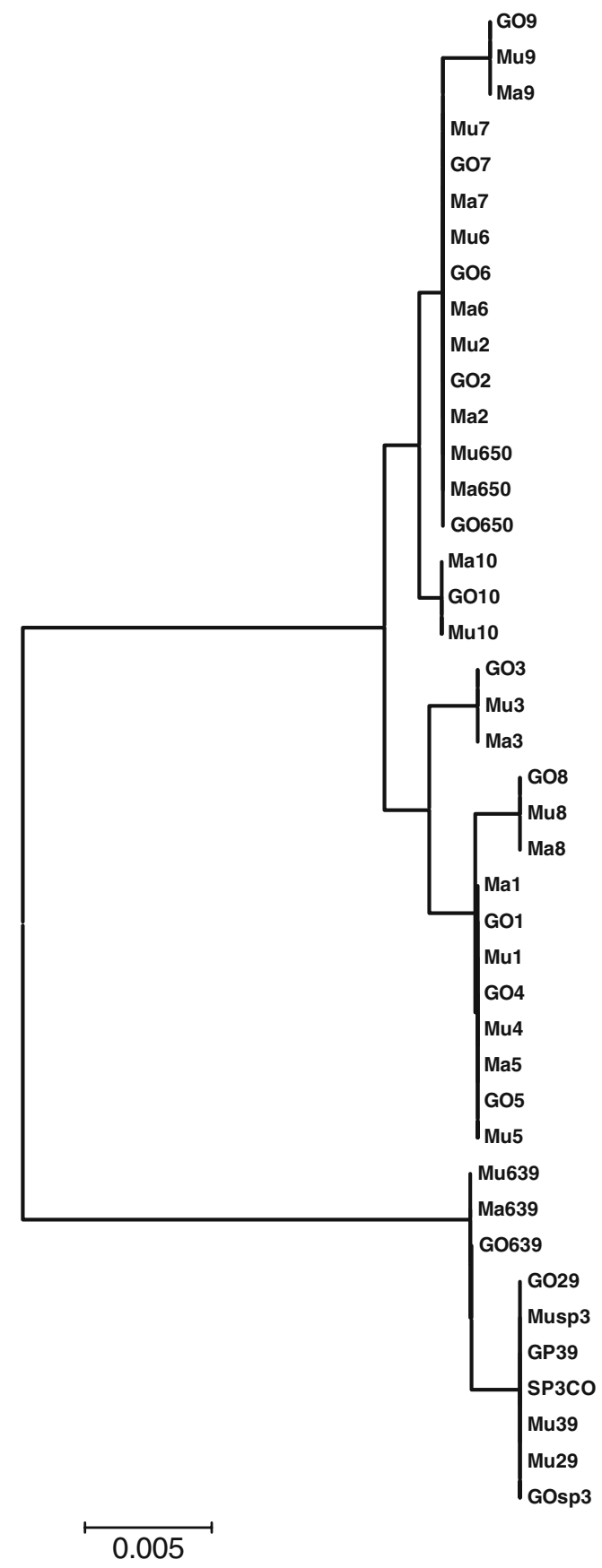

Fig. $5 \mathrm{NJ}$ analysis of the different mt COI from different tissues of different genitors collected in Brittany (France). Different H. tuberculata tuberculata haplotypes were analyzed as well as three $H$. tuberculata coccinea haplotype (individual 639, 29, 39, and sp3). No tissue segregation was evidenced

\section{Results and Discussion}

Taxonomic Status of Haliotis tuberculata Subspecies

Two types of molecular markers have been generally used to determine the taxon status. Among nuclear markers, the rDNA is the most popular while mitochondrial subunit I is 
Table 2 Microsatellite assignment of the seven genitors used for detection of hybrids

\begin{tabular}{|c|c|c|c|c|c|c|c|c|}
\hline Microsatellite/individual & Haltub01 & Haltub07 & Haltub09 & Haltub13 & Haltub16 & Haltub22 & Haltub24 & Haltub25 \\
\hline $\mathrm{H} 1=\mathrm{G} 16 \times \mathrm{G} 1$ & $176-184$ & $207-213$ & $133-136$ & $193-196$ & $187-197$ & $81-84$ & $130-136$ & $127-152$ \\
\hline G1 & $176-184$ & $207-213$ & $133-153$ & $176-193$ & $187-197$ & $84-90$ & $130-136$ & $127-127$ \\
\hline G16 & NA & $193-207$ & NA & $187-196$ & $184-187$ & NA & $130-136$ & NA \\
\hline $\mathrm{H} 2=\mathrm{G} 14 \times \mathrm{G} 2$ & $176-190$ & $207-213$ & $133-150$ & $179-193$ & $191-208$ & $84-87$ & $130-136$ & $127-152$ \\
\hline G14 & $176-184$ & NA & $133-136$ & NA & NA & $84-87$ & NA & $127-130$ \\
\hline G2 & $190-193$ & $207-219$ & $143-150$ & $179-179$ & $188-191$ & $84-84$ & $130-130$ & $152-152$ \\
\hline $\mathrm{H} 3=\mathrm{G} 19 \times \mathrm{G} 3$ & $176-187$ & $193-213$ & $153-163$ & $176-193$ & $187-198$ & $84-90$ & $130-136$ & $127-152$ \\
\hline G3 & $176-184$ & $213-216$ & $136-163$ & $193-193$ & $187-198$ & $84-90$ & $130-139$ & $127-152$ \\
\hline G19 & $181-187$ & $193-205$ & $153-153$ & $176-176$ & $187-198$ & $84-93$ & $136-139$ & $127-152$ \\
\hline $\mathrm{H} 4=\mathrm{G} 15 \times \mathrm{G} 2$ & $176-190$ & $207-219$ & $143-159$ & 179-204 & $187-198$ & $81-84$ & $130-136$ & $130-152$ \\
\hline G2 & $190-193$ & $207-219$ & $143-150$ & $179-179$ & $187-191$ & $84-84$ & $130-130$ & $152-152$ \\
\hline G15 & $176-176$ & $207-222$ & $136-159$ & $172-204$ & $187-198$ & $81-87$ & $130-136$ & $130-130$ \\
\hline
\end{tabular}

Only one hybrid of each crossing was tested to confirm the bi-parental origins (experiment realized in spring 2009)

largely used. For this study, we selected two nuclear markers, 18S-ITS1 complex and sperm lysin gene, and the mitochondrial COI marker for subspecies identification.

The different amplicons obtained for $H$. tuberculata tuberculata and $H$. tuberculata coccinea for the 18S-ITS1 segments were sequenced. The 18S-ITS1 sequences were deposited in the NCBI database as FJ605492 and FJ605493 for $H$. tuberculata tuberculata from Normandy and $H$. tuberculata coccinea from Grand Canary Island, respectively. The size of the sequences corresponding to $18 \mathrm{~S}$ fragments was $1,677 \mathrm{bp}$ in length. They were $100 \%$ identical to the published sequence of Giribet and Wheeler (2002). The size of the ITS1 sequences alone was $262 \mathrm{bp}$ and presented little variation (Fig. 1), as had previously been seen to be the case in the Haliotidae (Coleman and Vacquier 2002). Only one substitution has been detected between Mediterranean and Atlantic H. tuberculata subspecies (W to A in position 122), while in our sequence of H. tuberculata tuberculata, also from Brittany, a T (instead of a A) was detected at this position. This position could be highly variable according to the individuals. These ITS1 sequences were characterized by an 18-bp deletion, between bp 70 and bp 89, by comparison both with Haliotis diversicolor and Haliotis rugosa sequences. This deletion was also detected in Haliotis marmorata (Fig. 1), which has been considered as a sister species (Van Wormhoudt et al. 2009). For Haliotis discus and $H$. diversicolor (Wang et al. 2004), although the 18S rRNA sequence is identical, the divergence for ITS1 ranged from 9.3 to $18.5 \%$, which showed the efficiency of this marker in separating species but was not enough to separate subspecies in our case.

Sperm lysin acrosomal protein interacts with the vitelline envelope receptor for lysin to dissolve the vitellin envelope and was used to separate the subspecies. mRNA and sperm lysin proteins constituted good markers as suggested by Clark et al. (2007). In our case, 2.2\% divergence was measured between the corresponding two genes in the two recognized subspecies $H$. tuberculata tuberculata and $H$. tuberculata coccinea. The sequences were deposited in genbank as accession numbers HMO47082 and HMO47083. Their analysis confirmed also that $H$. marmorata (HMO47085) constituted a sister species of $H$. tuberculata. Three deletions, in position 77-134, 231-240, and 476-480, were detected between $H$. marmorata and $H$. tuberculata, and only two deletions with $H$. coccinea (Fig. 2). All the individuals from Brittany belonged to $H$. tuberculata tuberculata subspecies (Fig. 3a). This marker was equally efficient in discriminating species or subspecies.

The mitochondrial gene COI was used in many intraand interspecific studies (An et al. 2005; Gruenthal and Burton 2005, 2008; Wang et al. 2004) and separated the different Haliotidae species effectively (Van Wormhoudt et al. 2009). In our case, the sequencing of 565 bp length of

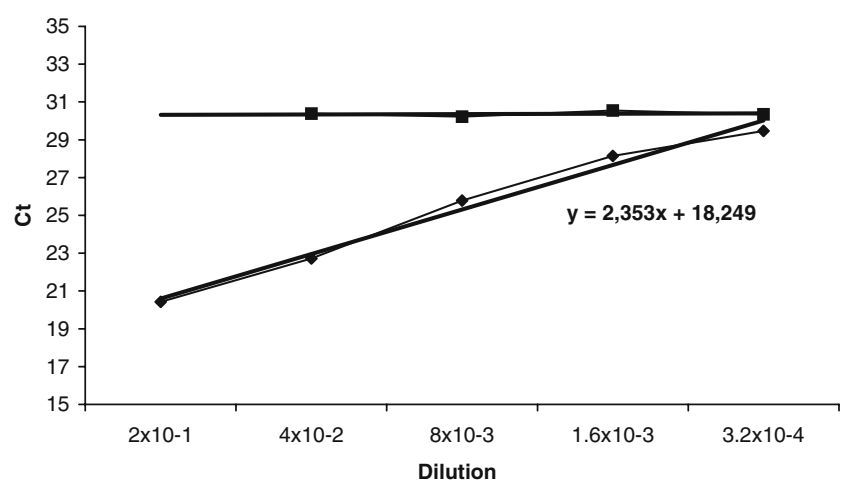

Fig. 6 Control of the specificity of two specific primers for $H$. tuberculata tuberculata ITS1 tested on $H$. tuberculata tuberculata and $H$. tuberculata coccinea. The dilution factor was $1 / 5$, and the efficiency was around $100 \%$ 
the $3^{\prime}$ end of the mitochondrial gene coding for COI revealed the presence of 24 polymorphic informative sites for the different $H$. tuberculata tuberculata selected (Fig. 4). This molecular marker only reveals nucleotidic diversity and the differentiation of two different main haplotypic clades for $H$. tuberculata tuberculata individuals: "Clade 1" and "Clade 2" (Fig. 3b). We should note that the mtDNA Clade 1 was mostly represented in Northern $H$. tuberculata tuberculata populations, and Clade 2 was mainly represented in the $H$. tuberculata coccinea Canary Islands population (Van Wormhoudt et al. 2009). It confirmed the results of Clark et al. (2007), who showed that this marker is not reliable in separating the different subspecies. However, this marker, which presented mostly a maternal inheritance and rare recombination events, may be maintained in the populations after introgression during a longer time than the nuclear marker, for which backcrosses imply the loss of $50 \%$ of nuclear material introduced by the introgressing parent at each generation. In our case, the actual clade ratio could be the reflection of a past contact between the two subspecies leading to crossintrogression between these two subspecies.

In this study, the three markers used provided different information concerning the status of the European abalone. 18S-ITS1 only permitted the separation of the different species whereas the sperm lysin gene was reliable in separating the different $H$. tuberculata subspecies. COI, which revealed the presence of an introgression in the $H$. tuberculata tuberculata subspecies, has been used for phylogeographic studies (Roussel et al. 2010). Moreover, as the two clades could be found in the same population of H. tuberculata tuberculata, this marker was used here to provide evidence of putative paternal inheritance and mtDNA recombination.

Presence of Two mtDNA in Some Individuals and Tissue Repartition

By using specific probes, in qPCR, we showed the presence of the two types of mtDNA sequences in $20 \%$ of the selected individuals taken as genitors from a natural Brittany population, with a ratio ranging from $1 / 32$ to 1/256: 19 of the 24 genitors presented only one mtDNA (Table 1). In order to see if there was a difference between the different tissues, the $\mathrm{mt}$ COI sequences from 11 individuals taken in the vicinity of Plouguerneau (Brittany) during the period of reproduction were analyzed. No difference was evidenced between mantle, muscle, and gonads (Fig. 5). The PCR analysis showed that two of these individuals (nb 1 and 3) presented the two mtDNA sequences, but the sequence of lysin gene indicated that they correspond to backcrossed individuals (sequences not shown). The situation was different in mussels where two sex-related mtDNAs have been detected (Skibinski et al. 1994a, b; Zbawicka et al. 2010) with a divergence rate ranging from $15 \%$ to $30 \%$ between mito $\mathrm{M}$ and mito $\mathrm{F}$ (Breton et al. 2006) and where the male mtDNA is transmittable from father to sons only (Zouros et al. 1992; Saavedra et al. 1997).

\section{Paternal mt Inheritance}

Due to the high number of crossings in the hatchery, assignment of individuals after the larvae fixation was

Table 3 Sequences of the different amplicons obtained after qPCR specific with specific primers for hybrids

\begin{tabular}{|c|c|c|c|c|c|c|c|c|}
\hline \multirow[t]{2}{*}{ Genitor } & \multirow[t]{2}{*}{ Hybrid } & \multicolumn{7}{|c|}{ Nucleotide change } \\
\hline & & 71 & 95 & 119 & 146 & 152 & 158 & 167 \\
\hline G1 & & $\mathrm{T}$ & $\mathrm{T}$ & $\mathrm{G}$ & $\mathrm{C}$ & $\mathrm{G}$ & $\mathrm{C}$ & $\mathrm{T}$ \\
\hline $\mathrm{G} 2$ & & $\mathrm{C}$ & $\mathrm{C}$ & G & $\mathrm{T}$ & A & $\mathrm{T}$ & $\mathrm{C}$ \\
\hline G3 & & $\mathrm{T}$ & $\mathrm{T}$ & G & $\mathrm{C}$ & G & $\mathrm{C}$ & $\mathrm{T}$ \\
\hline G14 & & $\mathrm{T}$ & $\mathrm{T}$ & G & $\mathrm{C}$ & G & $\mathrm{C}$ & $\mathrm{T}$ \\
\hline G15 & & $\mathrm{C}$ & $\mathrm{C}$ & $\mathrm{A}$ & $\mathrm{T}$ & $\mathrm{A}$ & $\mathrm{T}$ & $\mathrm{C}$ \\
\hline G16 & & $\mathrm{C}$ & $\mathrm{C}$ & $\mathrm{A}$ & $\mathrm{T}$ & $\mathrm{A}$ & $\mathrm{T}$ & $\mathrm{C}$ \\
\hline \multirow[t]{5}{*}{ G19 } & & $\mathrm{T}$ & $\mathrm{C}$ & G & $\mathrm{C}$ & G & $\mathrm{C}$ & $\mathrm{T}$ \\
\hline & $\mathrm{G} 16 \times \mathrm{G} 1$ & $\mathrm{C}-\mathrm{T}$ & $\mathrm{C}-\mathrm{T}$ & $\mathrm{A}-\mathrm{G}$ & $\mathrm{C}-\mathrm{T}$ & $\mathrm{A}-\mathrm{G}$ & $\mathrm{T}-\mathrm{C}$ & $\mathrm{C}-\mathrm{T}$ \\
\hline & $\mathrm{G} 14 \times \mathrm{G} 2$ & $\mathrm{~T}-\mathrm{C}$ & $\mathrm{T}-\mathrm{C}$ & G & $\mathrm{C}-\mathrm{T}$ & $\mathrm{G}-\mathrm{A}$ & $\mathrm{C}-\mathrm{T}$ & $\mathrm{T}-\mathrm{C}$ \\
\hline & $\mathrm{G} 19 \times \mathrm{G} 3$ & $\mathrm{~T}$ & $\mathrm{C}$ & G & $\mathrm{C}$ & G & $\mathrm{C}$ & $\mathrm{T}-\mathrm{C}$ \\
\hline & $\mathrm{G} 15 \times \mathrm{G} 2$ & $\mathrm{C}$ & $\mathrm{C}$ & A & $\mathrm{T}$ & A & $\mathrm{T}$ & $\mathrm{C}$ \\
\hline
\end{tabular}

Amplicons were sequenced with specific primers on both strands. Concerning the genitors, the COI sequence corresponded to the main mitochondrial signature (tub=clade 1 and cocc=clade 2). G1, G3, and G14 presented the same clade 1 haplotype while G19 presented 1-bp change. G15 and G16 presented the same clade 2 haplotype while G2 and presented 1-bp difference. Only the positions of the different mutated base pairs are indicated. Position 71 of the amplicon corresponded to position 231 of the COI sequenced in Fig. 4 
necessary to exclude fertilization of eggs with sperm coming from different individuals. The use of eight microsatellites for assignment confirmed the uniparental crossing (Table 2).

Three individuals of each clade previously determined were selected: G1, G3, and G14, which belonged to clade 1 , and G2, G15, and G16, which belonged to clade 2 (Fig. 3b). The experimental hybridization between these individuals demonstrated the transfer of paternal mitochondrial COI (Table 1). Due to the presence of a dominant mtDNA and the absence of tissue specific distribution, it was assumed that only one mtCOI was transmitted. The observed ratio was around 1/512 for small juveniles on the basis of the qPCR assay (Fig. 6), which was specific for $H$. tuberculata tuberculata and $H$. tuberculata coccinea COI respectively. The sequencing of the different amplicons obtained after specific quantitative amplifications confirmed the presence of the two specific sequences in the different hybrids (Table 3).

By using qPCR as described by Steurwald and Barrit (2000) and Vadopulas et al. (2006), we have demonstrated that this transfer is experimentally possible but difficult to detect due to the difference in mtDNA levels between spermatozoa and oocytes. We have found the same ratio of $1 / 512$, independent of the direction of fertilization. This ratio could be related to the difference of mitochondrial DNA content between spermatozoa and oocytes. The number of mitochondria within spermatozoa differs according to the species, and for H. ovina, it was assumed to be five (Singhakaew et al. 2003). However, the number of mitochondrial DNA copies was not known; it was considered to be around 10-100 in humans (May-Panloup et al. 2006) per spermatozoon, whereas in a human oocyte, this number (May-Panloup et al. 2004) is estimated at between 10,000 and 100,000.

The higher ratio measured (between 1/32 and 1/256) in adults suggest that hybridization may have occurred many times in the past or that paternal mtDNA has a better stability during development. The search for different mtDNA haplotypes in one individual, which could came from different past contact events between the different subspecies, should be used for further phylogeographic studies. Yet, in eight of the genitors (out of a total of 24: Table 1), a lower efficiency of the specific PCR reaction was detected. It was often (at least five times) associated with the presence of the two mtDNA after hybridization, and we hypothesized, in this case, that these specific primers, differing only by one nucleotide, may enter into competition during the first steps of annealing.

Nevertheless, our results not only confirmed paternal inheritance of mtDNA but also infirmed the specific destruction of the paternal mitochondrial during H. tuberculata development (Rantanen and Larsson 2000).

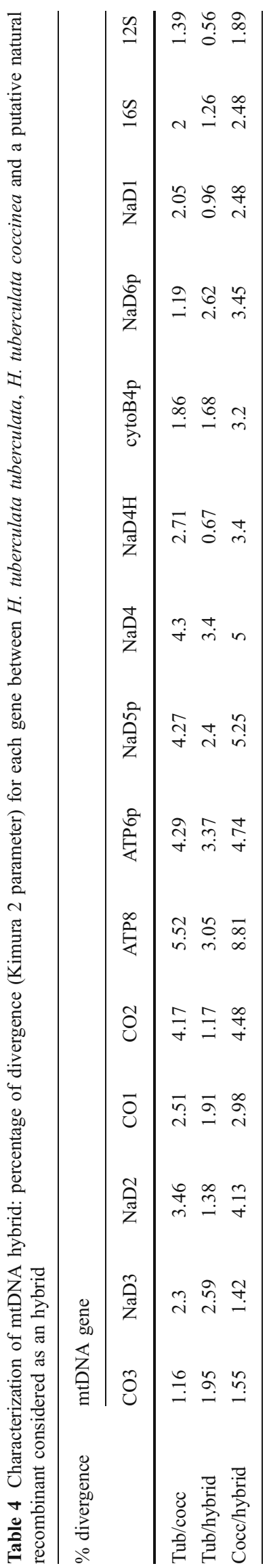




\section{Existence of a mtDNA Hybrid in Natural Population}

After the sequencing of around 700 mitochondrial COI, an mtDNA hybrid between $H$. tuberculata tuberculata and $H$. tuberculata coccinea mtDNA was detected in Normandy (Agon Coutainville) where the actual ratio of $H$. tuberculata coccinea/H. tuberculata tuberculata $\mathrm{mt}$ CO I introgression is the largest reported: around 30\%. The nearly complete mitochondrial hybrid sequence (NCBI database entry FJ 605488) spanned 15,938 bp and was compared with the $16,521 \mathrm{bp}$ for $H$. tuberculata tuberculata (FJ 599677) and the 16,358 bp for H. tuberculata coccinea (FJ605488) mitochondrial sequences. The rates of nucleotide divergence are comparable between the two subspecies and between the two subspecies and the hybrid, and range from $2.7 \%$ to $3.7 \%$. The gene organization was similar to that observed for the two other subspecies (Van Wormhoudt et al. 2009) with 13 protein-coding genes, 22 tRNAs genes, and two rRNA genes in the same order. The percentage of divergence of all the coding genes of this hybrid ranged from $0.56 \%$ to $3.40 \%$ with $H$. tuberculata tuberculata and from $1.42 \%$ to $8.8 \%$ with $H$. tuberculata coccinea (Table 4 ). If we refer to the number of bp changes in the sequences of the coding genes, $234 \mathrm{bp}$ was different with $H$. tuberculata tuberculata and 412 bp with $H$. tuberculata coccinea. Among them, 140 bp was specific to the hybrid (Table 5). $\mathrm{CO}$ III and $\mathrm{NaD} 3$ presented more similarity between hybrid and $H$. tuberculata coccinea while the other genes presented more similarity with $H$. tuberculata tuberculata. The ratio of non-synonymous/synonymous base was variable according to the gene considered (Table 5) and ranged from $11 \%$ to $21 \%$ between hybrid, and $H$. tuberculata tuberculata and $H$. tuberculata coccinea, respectively.

This rare haplotype presented some specific mutations, which may indicate either an ancient recombination event between the two mtDNAs of the two subspecies or an introgressed mtDNA from a now extinct taxon or the subsistence of an ancient nearly extinct mitochondrial lineage subsequently to the separation of the two subspecies.

The presence of two mtDNAs in some individuals and the paternal inheritance of this mtDNA may have indicated that recombination of mtDNA could be possible in Haliotis. One recombined clone of the mitochondrial large ribosomal subunit RNA gene $(r r n L)$, out of 30 analyzed sequences, was already obtained from the somatic tissues of Tapes philippinarum (Passamonti et al. 2003; Burzynski et al. 2003), presenting a series of diagnostic sites of maternal origin in a male specific mtDNA. It was the first putative case of recombination detected in molluscans. This type of recombination was also detected before in insects (Kondo et al. 1992) and more recently in human cells (Eyre-Walker and Awadalla 2001; D'Aurelio et al. 2004) by using mutated mitochondrial genes and was found not to be so rare (Tsaousis et al. 2005).

Regarding the evolutionary history of the two-lineage $H$. tuberculata tuberculata and $H$. tuberculata coccinea, the approximate separation time can be evaluated to 1 mya if we consider $2.5 \%$ COI divergence in base composition (Tables 4) and 5 for 1 my (Imron et al. 2007). Strong currents may have been established (Rouchy 1999), following the opening of the Gibraltar strait (Doadrio and Perdices 2005; Loget and den Driessche 2006; Warny et al. 2003). These currents may therefore be responsible for the implementation of a physical barrier to larval scattering between the African and European continents. Later, the last "glaciations" should have affected these currents, leading to secondary contacts between the two subspecies and the regulation of the larval scattering and settlement. Recombination occurred probably during this period, when the level of the sea underwent great changes. In the case of

Table 5 Characterization of mtDNA hybrid: differences in the number of bp for each gene between $H$. tuberculata tuberculata, H. tuberculata coccinea and a putative natural recombinant considered as an hybrid

nb changes mtDNA protein-coding gene

\begin{tabular}{|c|c|c|c|c|c|c|c|c|c|c|c|c|c|c|}
\hline & $\mathrm{CO} 3$ & $\mathrm{NaD} 3$ & $\mathrm{NaD} 2$ & $\mathrm{CO} 1$ & $\mathrm{CO} 2$ & ATP8 & ATP6 & $\mathrm{NaD} 5$ & $\mathrm{NaD} 4$ & $\mathrm{NaD} 4 \mathrm{H}$ & cytob4 & $\mathrm{NaD6}$ & $\mathrm{NaD} 1$ & Total \\
\hline Length: bp & 780 & 354 & 1,098 & 1,542 & 668 & 168 & 696 & 1,740 & 1,293 & 300 & 1,140 & 507 & 948 & 11,234 \\
\hline $\mathrm{Tub} / \operatorname{cocc} \mathrm{S}$ & 9 & 6 & 27 & 32 & 26 & 6 & 25 & 55 & 48 & 8 & 15 & 3 & 20 & 280 \\
\hline Tub/cocc NS & 0 & 2 & 10 & 5 & 2 & 3 & 4 & 17 & 6 & 0 & 6 & 3 & 1 & 59 \\
\hline Tub/hybrid S & 15 & 7 & 13 & 28 & 9 & 4 & 22 & 35 & 40 & 2 & 14 & 12 & 9 & 210 \\
\hline Tub/hybrid NS & 0 & 2 & 2 & 3 & 0 & 1 & 1 & 6 & 3 & 0 & 5 & 1 & 0 & 24 \\
\hline Cocc/hybrid S & 12 & 5 & 32 & 35 & 27 & 10 & 27 & 71 & 56 & 10 & 25 & 13 & 20 & 343 \\
\hline Cocc/hybrid NS & 0 & 0 & 12 & 6 & 2 & 4 & 5 & 17 & 7 & 0 & 11 & 4 & 1 & 69 \\
\hline Sp hybrid & 9 & 2 & 11 & 18 & 3 & 5 & 10 & 26 & 18 & 2 & 17 & 12 & 7 & 140 \\
\hline
\end{tabular}

Differences in the number of bp for each gene of mtDNAs from $H$. tuberculata tuberculata, $H$. tuberculata coccinea, and a putative natural recombinant considered as a hybrid. The number of synonymous $(S)$ and non-synonymous $(N S)$ differences are indicated for each mt gene $S p$ hybrid correspond to the number of specific changes for the recombinant 
the presence of an ancient lineage, the use of the COI mtDNA clock permits to define the age of this lineage. If we consider $1.91 \%$ and $2.98 \%$ divergence between the hybrid, and $H$. tuberculata tuberculata or $H$. tuberculata coccinea, respectively, this hybrid may correspond to an ancient haplotype from $H$. tuberculata tuberculata, which appeared 0.8 mya.

Other studies based on more samples are necessary to solve this question. H. tuberculata may be also an interesting material to study experimental recombination since all the steps of development are under control. However, if upon cell division the probability to segregate recombination in sperm cell is probably very low as we have not yet found recent recombinants in the field, it should be expected that these putative recombinants in some tissues are found.

In the three hypotheses, mutations would have changed the recombinant, as well as parental genomes, mixing the signatures and recombination with the noise of subsequent substitutions as suggested by Rokas et al. (2003). In our case, all the regions of the mitochondrial genome are different from both subspecies, suggesting that recombination may involve different mtDNA regions at the same time. Recently, the description of an ancient recombination between the Atlantic salmon and the brown trout gene ND1 (Ciborowsky et al. 2007) was described, but nothing was said about the other genes. The mechanism leading to mtDNA recombinant "hot spots" remains yet to be determined, and the use of cell fusion remains very promising.

\section{Conclusions}

The fact that Haliotidae revealed some important features from an evolutionary point of view could be due to their long evolution history, with the earliest fossils detected around 60-75 mya, to the speciation and to the large worldwide distribution. The isolation of $H$. tuberculata 1.5 mya allowed the separation of two subspecies, which later, during Pleistocene glaciations, came into contact. Introgression of mtDNA constituted a trace of these events. It allows the demonstration of paternal inheritance of mitochondrial DNA that could explain the existence of $\mathrm{mt}$ recombination. A good stability of this transmitted DNA may also explain the persistence of natural hybrids. Meanwhile, the mechanisms by which it happened are far from being resolved.

Acknowledgements This work was supported by ECC (SUDEVAB no. 222156 "Sustainable development of European SMEs engaged in abalone aquaculture"). We thank Olivier Basuyaux from the SMEL, Centre expérimental, ZAC de Blainville, 50560 Blainville/mer, for giving us the samples from Normandy.

\section{References}

An HS, Jee YJ, Min KS, Kim BL, Han SJ (2005) Phylogenetic analysis of six species of pacific abalone (Haliotidae) based on DNA sequences of 16S rRNA and cytochrome $C$ oxidase subunit I mitochondrial genes. Mar Biotechnol 7:373-380

Birky CW (1995) Uniparental inheritance of mitochondrial and choroplast genes: mechanisms and evolution. Proc Natl Acad Sci USA 92:11331-11338

Breton S, Burger G, Stewart DT, Blier PU (2006) Comparative analysis of gender-associated complete mitochondrial genomes in marine mussels (Mytilus spp). Genetics 172(2):1107-1119

Burzynski A, Zbawicka M, Skibinski DOF, Wenne R (2003) Evidence for recombination of mtDNA in the marine mussel Mytilus trossulus from the Baltic. Mol Biol Evol 20(3):388-392

Ciborowski KL, Consuegra S, Garcia de Leaniz C, Beaumont M, Wang J, Jordan WC (2010) Rare and fleeting: an example of interspecific recombination in animal mitochondrial DNA. Biol Lett 3:554-557

Clark NL, Findlay GD, Yi X, MacCoss MJ, Swanson WJ (2007) Duplication and selection on abalone sperm lysin in an allopatric population. Mol Biol Evol 24:2081-2090

Coleman AW, Vacquier VD (2002) Exploring the phylogenetic utility of sequences for animals: a test case for abalone (Haliotis). J Mol Evol 54:246-257

Courtois de Vicose G, Viera MP, Bilbao A, Izquierdo MS (2007) Embryonic and larval development of Haliotis tuberculata coccinea Reeve: an indexed micro-photographic sequence. J Shellfish Res 26:847-854

D'Aurelio M, Gajewski CD, Lin M, Mauck WM, Shao LZ, Lenaz G, Moraes C, Manfredi G (2004) Heterologous mitochondrial DNA recombination in human cells. Hum Mol Genet 13:31713179

Daume S, Huchette S, Ryan S, Day RW (2003) Nursery culture of Haliotis rubra: the effect of density on settlement and juvenile production. Aquaculture 236:221-239

Degnan SM, Imron GDL, Degnan BM (2006) Evolution in temperate and tropical seas: disparate patterns in southern hemisphere abalone (Mollusca: Vetigastropoda: Haliotidae). Mol Phylogenet Evol 41:249-256

Doadrio I, Perdices A (2005) Phylogenetic relationships among the Ibero-African cobitids (Cobitis, cobitidae) based on cytochrome B sequence data. Mol Phylogenet Evol 37:484-493

Doyle JJ, Doyle JL (1987) A rapid isolation procedure for small quantities of fresh leaf tissue. Phytochem bull 19:11-15

Elliott NG, Evans B, Conod N, Bartlett J, Officer R, Sweijd N (2000) Application of molecular genetics to the understanding of abalone population structure Australian and South African case studies. J Shellfish Res 19:510

Evans B, White RWG, Elliot NG (2000) The use of microsatellite markers for parentage analysis in Australian blacklip and hybrid abalone. J Shellfish Res 19:511

Eyre-Walker A, Awadalla P (2001) Does Human mtDNA recombine? J Mol Evol 53:430-435

Garrido-Ramos M, Stewart D, Sutherland BW, Zouros E (1998) The distribution of male-transmitted and female-transmitted mitochondrial DNA types in somatic tissues of the blue mussels: implications for the operation of doubly uniparental inheritance of mitochondrial DNA. Genome 41:818-824

Geiger DL (1999) A total evidence cladistic analysis of the haliotidae (Gastropoda vetigastropoda). $\mathrm{PhD}$, Univ. South California, $423 \mathrm{pp}$

Geiger DL (2000) Distribution and biogeography of Haliotidae (Gastropoda: Vetigastropoda) worldwide. Boll Malacol 35:57-120

Geiger DL, Poppe GT (2000) Haliotidae. In: Poppe GT, Groh K (eds) Conchological iconography. Conchbooks, Hackenheim, pp 66-89 
Giribet G, Wheeler WC (2002) On bivalve phylogeny in a highlevel analysis of the bivalvia (Mollusca) based on combined morphology and DNA sequence analysis. Invertebr Biol 121:271-324

Gruenthal KM, Burton RS (2005) Genetic diversity and species identification in the endangered white abalone (Haliotis sorenseni). Conserv Genet 6:929-939

Gruenthal KM, Burton RS (2008) Genetic structure of natural populations of the California black abalone (Haliotis cracherodii Leach, 1814) a candidate for endangered species status. J Exp Mar Biol Ecol 355:47-58

Hall TA (1999) BioEdit: a user-friendly biological sequence alignment editor and analysis program for Windows 95/98/NT. Nucl Acids Symp Ser 41:95-98

Hamm DE, Burton RS (2000) Population genetics of black abalone, Haliotis cracherodii, along the central California coast. J Exp Mar Biol Ecol 254:235-247

Hardy E (2007) Hardy's internet guide to marine gastropods: a virtual encyclopedia of sea snails

Huang BX, Peakall R, Hanna PJ (2000) Analysis of genetic structure of blacklip abalone (Haliotis rubra) populations using RAPD, minisatellite and microsatellite markers. Mar Biol 136:207-216

Huchette SMH, Clavier J (2004) Status of the ormer (Haliotis tuberculata L) industry in Europe. J Shellfish Res 23:951-955

Imron B, Hale P, Degnan BM, Degnan SM (2007) Pleistocene isolation and recent gene flow in Haliotis asinina, an IndoPacific vetigastropod with limited dispersal capacity. Mol Ecol $16: 289-304$

Kimura M (1980) A simple method for estimating evolutionary rate of base substitutions through comparative studies of nucleotide sequences. J Mol Evol 16:111-120

Kondo R, Matsura ET, Chigsura SI (1992) Further observations of paternal transmission of Drosophila DNA by PCR selected amplification method. Gene research 59:81-84

Kumar S, Tamura K, Nei M (2004) MEGA3: integrated software for molecular evolutionary genetics analysis and sequence alignment. Brief Bioinform 5:150-163

Ladoukatis ED, Zouros E (2001) Direct evidence for homologous recombinaison in mussel (Mytilus galloprovincialis) mitochondrial DNA. Mol Biol Evol 18:1168-1175

Lee Y, Vacquier VD (1992) The divergence of species-species abalone sperm lysin is promoted by positive Darwinienne selection. Biol Bull 182(1):97-104

Lee YH, Vacquier VD (1995) Evolution and systematics in Haliotidae (Mollusca: Gastropoda): inferences from DNA sequences of sperm lysin. Mar Biol 124(2):267-278

Loget N, den Driessche V (2006) On the origin of the Strait of Gibraltar. Sed Geol 188:341-356

Maynard BT, Kerr LJ, McKiernan JM, Jansen ES, Hanna PJ (2005) Mitochondrial DNA sequence and gene organization in Australian blacklip abalone Haliotis rubra (Leach). Mar Biotechnol 7:645-658

May-Panloup P, Chrétien MF, Malthiery Y, Reynier P (2004) Mitochondries et reproduction. Med Sci 29:779-783

May-Panloup P, Chrétien MF, Malthiery Y, Reynier P (2006) ADN mitochondrial du spermatozoide. Gyn Obst Fert 34:847-854

Mgaya YD, Gosling EM, Mercer JP, Donlon J (1995) Genetic variation at three polymorphic loci in wild and hatchery stocks of the abalone, Haliotis tuberculata Linnaeus. Aquaculture $136: 71-80$

Owen B, McLean JH, Meyer RJ (1971) Hybridization in the eastern Pacific abalones (Haliotis). Bull LA Co Mus Nat Hist Sci 9:1-37

Passamonti M, Boore JL, Scali V (2003) Molecular evolution and recombination in gender-associated mitochondrial DNAs of the Manila clam Tapes philippinarum. Genetics 164:603-611
Rantanen A, Larsson NG (2000) Regulation of mitochondrial DNA copy number during spermatogenesis. Hum Reprod 15:86-91

Rokas A, Ladoukakos E, Zouros E (2003) Animal mitochondrial DNA recombination revisited. Trends Ecol Evol 18:411-417

Rouchy JM (1999) Un événement exceptionnel: la crise de salinité méssinienne de Méditerrannée. In: Fröhlich F, Scubnell HJ (eds) Les âges de la terre. MNHN, Paris, pp 104-108

Roussel V, Huchette S, Van Wormhoudt A (2010) Isolation and characterization of eight microsatellite loci in the European abalone, Haliotis tuberculata. Mol Ecol Res 10:751-754

Saavedra C, Reyero ML, Zouros E (1997) Male-dependant doubly uniparental inheritance of mitochondrial sex-ratio in the mussel Mytilus galloprovincialis. Genetics 145:1073-1082

Scharzpaul K (2002) NCBI unpublished 18S rDNA sequence of Haliotis tuberculata

Selvamani MJP, Degnan SM, Paetkau D, Degnan BM (2000) Isolation and characterization of microsatellite DNA markers for the tropical abalone, Haliotis asinina. J Shellfish Res 19:532

Singhakaew S, Seehabutr V, Kruatrachae M, Sretarugsa P, Romratanapun S (2003) Ultrastructure of male germ cells in the testes of abalonen Haliotis ovina Gmelin. Mol Res 23:109-121

Skibinski DO, Gallagher C, Beynon CM (1994a) Mitochondrial DNA inheritance. Nature 368:817-818

Skibinski DOF, Gallagher C, Beynon CM (1994b) Sex-limited mitochondrial DNA transmission in the marine mussel Mytilus edulis. Genetics 138:801-809

Steurwald N, Barrit JA (2000) Adler R (2000) Quantification of mtDNA in single oocytes, polar bodies and subcellular components by real-time rapid cycle fluorescence monitored PCR. Zygote 8:209-2015

Swanson WJ, Aquadro CF, Vacquier VD (2001) Polymorphism in abalone fertilization proteins is consistent with the neutral evolution of the egg's receptor for lysin (VERL) and positive Darwinian selection of sperm lysin. Mol Biol Evol 18:376383

Tamura K, Dudley J, Nei M, Kumar S (2007) MEGA4: Molecular Evolutionary Genetics Analysis (MEGA) software version 4.0. Mol Biol Evol 24:1599-1996

Tang S, Popongviwat A, Klinbunga S, Tassanakajon A, Jarayabhand P, Menasveta P (2005) Genetic heterogeneity of the tropical abalone (Haliotis asinina) revealed by RAPD and microsatellite analyses. J Biochem Mol Biol 38:182-190

Tsaousis AD, Martin DP, Ladoukakis ED, Posada D, Zouros E (2005) Widespread recombination in published animal mtDNA sequences. Mol Biol Evol 22(4):925-933

Vacquier VD, Swanson WJ, Lee YH (1997) Positive Darwinian selection on two homologous fertilization proteins: what is the selective pressure driving their divergence? J Mol Evol 44:S15-S22

Vadopulas B, Bouma JV, Jackels CR, Friedman CS (2006) Application of real time PCR for simultaneous identification of larval abalones. J Exp Mar Biol Ecol 334:219-228

Van Wormhoudt A, Le Bras Y, Huchette S (2009) Haliotis marmorata from Senegal; a sister species of $H$. tuberculata: morphological and molecular evidence. Biochem Syst Ecol 37:747-757

Wang Z, Ho KC, Yu DH, Ke CH, Mak WY, Chu KH (2004) Lack of genetic divergence in nuclear and mitochondrial DNA between subspecies of two Haliotis species. J Shellfish Res 23:1143-1146

Warny SA, Bart PJ, Suc JP (2003) Timing and progression of climatic, tectonic and glacioeustatic influences on the Messinian Salinity Crisis. Palaeogeogr Palaeoclimatol Palaeoecol 202(1-2):59-66

Zbawicka M, Burzynski A, Skibinski D, Wenne R (2010) Scottish Mytilus trossulus retaining ancestral mitochondrial DNA: complete sequences of male and female mtDNA genomes. Gene 456(1-2):45-53

Zouros E, Freeman KR, Ball AO, Pogson GH (1992) Direct evidence for extensive paternal mitochondrial DNA inheritance in the marine mussel Mytilus. Nature 359:412-414 